\title{
Branża wydobywcza w obliczu wyzwań niesionych przez ideę zrównoważonego rozwoju
}

Klaudia BOGUSZ ${ }^{1}$

\author{
${ }^{1)}$ mgr; KGHM Polska Miedź S.A., Uniwersytet Ekonomiczny we Wrocławiu; email: klaudia.bogusz@kghm.com, klaudia.bogusz@ue.wroc.pl
}

\section{http://doi.org/10.29227/IM-2020-01-21}

Submission date: 24-01-2020 | Review date: 09-04-2020

Abstrakt
Kryzys klimatyczny i jego następstwa stanowią dziś temat rozpalający szeroką dyskusję wśród wielu środowisk. Silna presję na władze
państwowe, ale także pośrednio na świat biznesu, nałożył w 2015 roku ONZ, uchwalając Agendę 2030. Chęć przystapienia do działań
na rzecz zrównoważonego rozwoju (ZR) wyraziły 193 państwa. Jak odnajduje się w tym biznes? Jak radza sobie branże zwyczajowo
uznawane za szkodliwe dla środowiska, np. górnictwo? Czy oznacza to ich koniec? Te i inne pytania rodza się po zapoznaniu z Agen-
dą 2030, znalezienie odpowiedzi na nie stanowi cel niniejszego artykułu. Okazuje się, że biznes, także sektory o wydawałoby się
negatywnym wydźwięku, w kontekście ich wptywu na środowisko, z nowego ładu potrafia czynić przewagę konkurencyjną. Aspekty
związane z ZR znajduja swoje odzwierciedlenie w znakomitej większości strategii największych spółek wydobywczych na świecie.
Kierunki wyznaczane przez ZR przynosza korzyści otoczeniu przedsiébiorstw, ale już dziś widać wyraźny trend, w którym spółki
swoją odpowiedzialną i zrównoważona postawę starają się przekuwać na własny sukces.

Słowa kluczowe: zrównoważony rozwój, branża wydobywcza, interesariusze, wyzwania

\section{Zmiany klimatyczne katalizatorem zmian w prowadze- niu biznesu}

1.1. Ewolucja podejścia do prowadzenia działalności przez branżę wydobywcza

Obserwowana od kilku lat silna presja na walkę o ochronę środowiska naturalnego i przeciwdziałanie zmianom klimatycznym osiągnęły swoje apogeum w minionym, 2019 roku. Z przekazów medialnych płynęły setki informacji i działających na świadomość obrazów. Środowiska proekologiczne, młodzież z całego świata oraz organizacje walczące o szerokorozumiane dobro planety biły na alarm, apelując do światowych przywódców, ale i do przedstawicieli świata biznesu o opamiętanie i zmianę podejścia do produkcji i konsumpcji. W totalnej opozycji stał największy klimatyczny negacjonista - prezydent światowej potęgi gospodarczej, jaką są Stany Zjednoczone Ameryki, Donald Trump. Definitywny wyraz swojego sceptycyzmu w stosunku do zmian klimatycznych wynikających z działalności człowieka dał podejmując decyzję o rozpoczęciu procesu wycofywania USA z porozumienia paryskiego [1]. Nie jest celem artykułu rozsądzanie o racjach którejkolwiek ze stron. Niezaprzeczalnym jest jednak, że ochrona środowiska i zrównoważony rozwój, co najmniej od początku nowego tysiąclecia coraz silniej wpływają na kształt i formę prowadzenia biznesu na świecie. W ostatnich dziesięcioleciach inwestycje w przyjazny dla środowiska biznes rosły w szybkim tempie w prawie wszystkich sektorach gospodarki. Dzisiaj, za sprawą szerzenia idei zrównoważonego rozwoju, ekologia stała się jednym z głównych trendów współczesnego biznesu i zmieniła postrzeganie środowiska przez prawie wszystkich członków otoczenia biznesu [2].

Postrzeganie istoty zrównoważonego rozwoju podlegało stopniowej ewolucji. U swych podstaw zrównoważony rozwój postrzegano przede wszystkim jako nurt, który powinien stanowić obszar zainteresowania rządów państw. Koncepcję przedstawiano przede wszystkim przez pryzmat środowi- skowy, traktując ją jako konieczną, aby myśleć o przyszłości ziemi, jako planety i kolejnych pokoleń ją zasiedlających. Kolejne raporty organizacji międzynarodowych (głównie „Granice wzrostu” z 1972 roku i „Nasza wspólna przyszłość” z 1987 roku) [3] zwracały uwagę na degradacyjny charakter działalności człowieka i jego dramatyczny wpływ na kondycję planety. Uznano, że dalszy rozwój społeczeństwa musi w jak najmniejszym stopniu przekształcać środowisko przyrodnicze Ziemi i zapewniać równy dostęp do dóbr kolejnym pokoleniom [4]. Początek nowego milenium przyniósł stopniową ewolucję postrzegania zagadnień związanych ze zrównoważonym rozwojem. Dostrzeżono, że chcąc działać w sposób zrównoważony, myśląc długofalowo o przyszłości ludzkości, koniecznym jest włączenie do tego planu sektora przedsiębiorstw. Biznes ma do odegrania w tym aspekcie ogromną rolę. Rok 2015 przyniósł światu, uchwaloną przez ONZ, Agendę Zrównoważonego Rozwoju 2030. Zawarte w niej 17 Celów Zrównoważonego Rozwoju (Sustainable Development Goals (SDGs)) zostało deklaratywnie przyjętych przez 193 kraje świata [5].

Kolejne lata to intensywna kampania promująca wyłonione cele. Rządy krajów rozwijających się w coraz większym stopniu zobowiązują się do ekologizacji swoich gospodarek. Wskutek przystąpienia do porozumienia paryskiego, w sprawie zmian klimatu, podjęto decyzje o budowie krajowych map drogowych dotyczących dekarbonizacji. Wiele państw wprowadziło kompleksowe krajowe strategie na rzecz zielonego wzrostu, aby budować własną zieloną gospodarkę. W tę ekologiczną rewolucję z rozmachem włącza się świat biznesu. Globalne koncerny ujmują SDGs w swoich strategiach biznesowych. Skrajnie zmieniają się oczekiwania względem przemysłu. Już nie wystarczy dostarczyć dobrej jakości produkt. Wiele dekad temu środowisko naturalne było po prostu źródłem surowców z jednoczesną funkcją odbiorcy odpadów, przyjmującym wszystko, co zostało wyeliminowane lub od- 


\begin{tabular}{|c|c|c|c|c|c|c|}
\hline & Europe & $\begin{array}{l}\text { North } \\
\text { America }\end{array}$ & $\begin{array}{l}\text { Latin } \\
\text { America }\end{array}$ & Asia & Africa & Oceania \\
\hline 1 & $\begin{array}{c}\text { Governance/ } \\
\text { regulations } \\
(26 \%)\end{array}$ & $\begin{array}{l}\text { Environmental } \\
\text { concerns } \\
(26 \%)\end{array}$ & $\begin{array}{c}\text { Water usage } \\
\text { (31\%) }\end{array}$ & $\begin{array}{l}\text { Environmental } \\
\text { concerns } \\
(39 \%)\end{array}$ & \multirow{2}{*}{$\begin{array}{c}\text { Environmental } \\
\text { concerns; } \\
\text { Price/cost pressures / } \\
\text { volatility } \\
\text { (each } 34 \% \text { ) }\end{array}$} & $\begin{array}{c}\text { Environmental } \\
\text { concerns } \\
(41 \%)\end{array}$ \\
\hline 2 & $\begin{array}{l}\text { Environmental } \\
\text { concerns } \\
(25 \%)\end{array}$ & \multirow{2}{*}{$\begin{array}{l}\text { Governance/ } \\
\text { regulations; } \\
\text { Social } \\
\text { concerns/legacy } \\
\text { issues/public image } \\
\text { (each 22\%) }\end{array}$} & $\begin{array}{l}\text { Governance/ } \\
\text { regulations } \\
(26 \%)\end{array}$ & $\begin{array}{c}\text { Price/cost pressures / } \\
\text { volatility } \\
(34 \%)\end{array}$ & & $\begin{array}{c}\text { Social } \\
\text { concerns/legacy } \\
\text { issues/public image } \\
(28 \%)\end{array}$ \\
\hline 3 & $\begin{array}{c}\text { Price/cost pressures / } \\
\text { volatility } \\
(21 \%)\end{array}$ & & $\begin{array}{l}\text { Environmental } \\
\text { concerns } \\
(24 \%)\end{array}$ & $\begin{array}{l}\text { Governance/ } \\
\text { regulations } \\
(29 \%)\end{array}$ & $\begin{array}{c}\text { Governance/ } \\
\text { regulations } \\
(32 \%)\end{array}$ & \multirow{2}{*}{$\begin{array}{l}\text { Price/cost pressures } \\
\text { volatility; } \\
\text { Governance/ } \\
\text { regulations } \\
\text { (each } 26 \% \text { ) }\end{array}$} \\
\hline 4 & \multirow{2}{*}{$\begin{array}{l}\text { Water usage; } \\
\text { Access to resources; } \\
\text { Social concerns / legacy } \\
\text { issues / nublic image; } \\
\text { Sustainable } \\
\text { development } \\
\text { (each 18\%) }\end{array}$} & \multirow[t]{2}{*}{$\begin{array}{c}\text { Price/cost pressures / } \\
\text { volatility } \\
(19 \%)\end{array}$} & $\begin{array}{c}\text { Social } \\
\text { concerns/legacy } \\
\text { issues/public image } \\
(22 \%)\end{array}$ & $\begin{array}{c}\text { Social } \\
\text { concerns/legacy } \\
\text { issues/public image } \\
(24 \%)\end{array}$ & & \\
\hline 5 & & & $\begin{array}{l}\text { Community } \\
\text { engagement (17\%) }\end{array}$ & Community conflict / & $\begin{array}{l}\text { Community conflict/ } \\
\text { lack of acceptance } \\
(16 \%)\end{array}$ & $\begin{array}{l}\text { Climate change } \\
(17 \%)\end{array}$ \\
\hline
\end{tabular}

Rys. 1. Pięć kluczowych wyzwań zidentyfikowanych dla branży górniczej na lata 2017-2021 w podziale na kontynenty [Źródło: ICMM 2017 Industry Stakeholders Opinion Survey Final Report]

Fig. 1. Five key challenges identified for the mining industry for 2017-2021 by continent [Source: ICMM 2017 Industry Stakeholders Opinion Survey Final Report]

rzucone, jako nieużyteczne $\mathrm{w}$ procesie produkcji lub już po konsumpcji [6]. Stopniowo zaczęły pojawiać się coraz bardziej restrykcyjne przepisy dotyczące ochrony środowiska naturalnego, które dla wielu stały się przeszkodą do rozwijania swojej działalności. W szczególnie trudnej sytuacji znalazły się podmioty $\mathrm{z}$ branży wydobywczej. Idea zrównoważonego rozwoju nabiera szczególnego znaczenia w przypadku górnictwa. Nieodłączną cechą tej branży jest to, że bazuje na wydobyciu surowców, będących zasobami nieodnawialnymi. Branża wydobywcza charakteryzuje się przez to specyficznymi uwarunkowaniami sektorowymi i często zarzuca się jej negatywne oddziaływanie na środowisko. Wśród teoretyków pojawiają się głosy, że górnictwo z założenia nie ma szans na bycie branżą funkcjonującą w zgodzie z ideą zrównoważonego rozwoju [7]. Zapomina się jednak, że z historycznego punktu widzenia górnictwo jest jednym z najstarszych udokumentowanych rodzajów działalności człowieka, o ogromnym znaczeniu dla jej rozwoju i postępu. Wydobywane i wykorzystywane surowce mineralne warunkowały rozwój gospodarczy i cywilizacyjny społeczeństw i państw, co zostało bardzo wyraźnie zaakcentowane w motcie 18. Światowego Kongresu Górniczego, który odbył się w 2000 roku w USA - „Everything begins with mining”. Można wskazać wiele obszarów zarówno w przeszłości, jak i w czasach współczesnych, które swój rozwój zawdzięczają właśnie rozwojowi górnictwa. W ostatnim 50-leciu obserwuje się wyraźną zmianę w dynamice wzrostu konsumpcji surowców naturalnych. Największy wzrost odnotowano w grupie surowców przemysłowych i konstrukcyjnych - odpowiadają za niego głównie kraje takie jak Chiny czy Indie. Fakt ten jednoznacznie wskazuje na zależność między wydobyciem tych surowców a rozwojem gospodarczym. Kluczowym elementem zrównoważonego rozwoju w zakresie pozyskiwania i korzystania z surowców mineralnych jest racjonalna i oszczędna gospodarka [8].

Przedsiębiorstwa górnicze na całym świecie coraz lepiej rozumieją swoją rolę i wpływ na cele zrównoważonego rozwoju. Branża mimo niechlubnej opinii dąży do tego, aby udowodnić, że nie stoi w opozycji do założeń zrównoważonego rozwoju i stara się je wspierać na wszelkie dostępne sposoby. $\mathrm{Z}$ badań przeprowadzonych przez International Council of
Mining and Metals (ICMM) [9] wynika, że zrównoważony rozwój jest dziś postrzegany, jako wyzwanie na kolejne lata dla branży górniczej, co pokazano na Rysunku 1.

Samoświadomość branży górniczej w aspekcie zrównoważonego rozwoju stale rośnie. Nie bez znaczenia są także świadomość i oczekiwania interesariuszy tejże branży, którzy niejako wymuszają na przedsiębiorstwach górniczych pewne zachowania. Bez względu na pobudki, niepodważalnym jest, że przedsiębiorstwa górnicze przyłączają się do realizacji celów zrównoważonego rozwoju i eksponują to na wiele sposobów.

\subsection{Oczekiwania interesariuszy konsekwencją szerzenia idei zrównoważonego rozwoju}

Presja prośrodowiskowa oraz dynamiczne szerzenie idei zrównoważonego rozwoju, która w dużej mierze wymusiła proces ewolucji w sposobie funkcjonowania biznesu, wpłynęły także na zmianę postaw wśród interesariuszy. Niegdyś tym, na czym zależało inwestorom był zysk, rozumiany wyłącznie w kategoriach księgowych. Generowany pieniądz był podstawowym, a często jedynym czynnikiem, który decydował o atrakcyjności inwestycyjnej przedsiębiorstwa. Dziś, korzyści czysto ekonomiczne dalej są ważne, ale na znaczeniu przybrały inne aspekty, wcześniej zupełnie pomijane. Dobre podsumowanie stanowią słowa P. Druckera: „Nie wystarczy osiągać korzyść, trzeba jeszcze czynić dobro, ale by czynić dobro, firma musi najpierw osiągnąć korzyść" [10]. Jasnym pozostaje, że dla przedsiębiorstw zysk będzie podstawowym celem, ale warto pamiętać, że już nie jedynym.

Wyraźnym odzwierciedleniem zmian oczekiwań względem biznesu jest wystosowane w 2018 roku wezwanie prezesa zarządu BlackRock - największej firmy inwestycyjnej na świecie, zarządzającej aktywami szacowanymi na 6,3 tryliona dolarów. BlackRock ma udziały w ponad 17 tys. spółek, $\mathrm{w}$ tym we wszystkich najważniejszych podmiotach notowanych na światowych giełdach i zarządza kapitałem powierzonym przez banki, fundusze emerytalne i rządy zlokalizowane w 100 krajach. Larry Fink, o którym mowa, w liście wystosowanym do prezesów spółek zaapelował o tworzenie jasnych, długofalowych strategii uwzględniających wpływ społeczny 
Tab. 1. Główne elementy strategii biznesowych KGHM Polska Miedź S.A. i Jastrzębskiej Spółki Węglowej S.A. [Źródło: Opracowanie własne na podstawie strategii biznesowych KGHM Polska Miedź S.A. i Jastrzębskiej Spółki Węglowej S.A.]

Tab. 1. The main elements of the business strategies of KGHM Polska Miedź S.A. and Jastrzębska Spółka Węglowa S.A. [Source: Own elaboration, based on the business strategies of KGHM Polska Miedź S.A. and Jastrzębska Spółka Węglowa S.A.]

\begin{tabular}{|l|l|}
\hline \multicolumn{1}{|c|}{$\begin{array}{c}\text { Strategia KGHM Polska } \\
\text { Miedź S.A. na lata 2019-2023 }\end{array}$} & \multicolumn{1}{c|}{$\begin{array}{c}\text { Strategia 2018-2030 z } \\
\text { uwzględnieniem Spólek Zależnych } \\
\text { GK JSW }\end{array}$} \\
\hline $\begin{array}{l}\text { KGHM 4.0 } \\
\text { (nawiązanie do czwartej rewolucji } \\
\text { przemysłowej tj. przemysłu 4.0) }\end{array}$ & $\begin{array}{l}\text { JSW 4.0 } \\
\text { (nawiązanie do czwartej rewolucji } \\
\text { przemysłowej tj. przemysłu 4.0) }\end{array}$ \\
\hline $\begin{array}{l}\text { Efektywność } \\
\text { (jako element 4E) }\end{array}$ & $\begin{array}{l}\text { Efektywność } \\
\text { (Program efektywność) }\end{array}$ \\
\hline $\begin{array}{l}\text { Elektromobilność } \\
\text { (punkty ładowania, wprowadzenie } \\
\text { elektrycznych samochodów do floty) }\end{array}$ & $\begin{array}{l}\text { Elektromobilność } \\
\text { (punkty ładowania, wprowadzenie } \\
\text { elektrycznych samochodów do floty) }\end{array}$ \\
\hline $\begin{array}{l}\text { Niezależność energetyczna } \\
\text { (50\% energii ze źródeł własnych i } \\
\text { OZE do 2030 r.) }\end{array}$ & $\begin{array}{l}\text { Niezależność energetyczna } \\
\text { (samowystarczalność energetyczna już } \\
\text { w 2022 r.) }\end{array}$ \\
\hline Fotowoltaika & Fotowoltaika \\
\hline Zrównoważony KGHM & Zielone JSW \\
\hline GOZ & GOZ \\
\hline
\end{tabular}

biznesu, podkreślając, że prowadzenie firmy, tak by generowała krótkotrwałe zyski dla inwestorów nie jest dziś akceptowalną formą zarządzania. Prezes BlackRock pisze wprost, że publiczne oczekiwania względem firm nigdy nie były większe. Uzasadnia, że społeczeństwo swoimi oczekiwaniami coraz bardziej zwraca się w kierunku sektora prywatnego z uwagi na nieudolność rządów w odpowiadaniu na szerokie wyzwania społeczne. W jednym z fragmentów Fink pisze „Społeczeństwo domaga się by firmy, zarówno publiczne jak i prywatne, służyły celom społecznym. By prosperować w długim czasie, każda firma musi nie tylko radzić sobie finansowo, ale też pokazywać, w jaki sposób pozytywnie udziela się społecznie. Firmy muszą dawać korzyści wszystkim swoim udziałowcom, $\mathrm{w}$ tym posiadaczom akcji, pracownikom, klientom oraz społecznościom, w których operują" [11].

W widoczny sposób z każdym rokiem wzrasta znaczenie nowych strategii inwestowania. Na sile zyskują szczególnie inwestycje społecznie odpowiedzialne. Zgodnie z ideą społecznie odpowiedzialnego inwestowania (Socially Responsible Investment - SRI) kwestie etyczne, społeczne i środowiskowe (ESG) mają priorytet wobec determinantów czysto finansowych. Jak już wspomniano, inwestorzy coraz częściej oprócz wartości ekonomicznej poszukują prospołecznych, ekologicznych i etycznych działań ze strony spółek, w które inwestują. Odpowiedzialne inwestowanie integruje czynniki ESG w analizach inwestycyjnych dotyczących doboru spółek oraz podczas korzystania z praw korporacyjnych w przekonaniu, że czynniki te mogą pozytywnie wpłynąć na długoterminową efektywność zarządzania [12]. Co istotne, SRI bierze pod uwagę różnice natury światopoglądowej i religijnej w różnych częściach świata, dlatego też bazuje na uniwersalnych wartościach etycznych wskazywanych np. w 17 Celach Zrównoważonego Rozwoju ONZ wyłonionych w ramach wspomnianej już Agendy 2030.

Wskaźniki ESG są dla inwestorów na tyle istotne, że na światowych giełdach pojawia się coraz więcej dedykowanych temu zagadnieniu indeksów, pomagających oceniać inwestorom pozafinansowe aspekty działalności spółek. W dniu 03.09.2019 roku także Giełda Papierów Wartościowych (GPW) w Warszawie uruchomiła nowy indeks - WIG-ESG, który od 01.01.2020 definitywnie zastąpił dotychczasowy Respect Index, zrzeszający spółki społecznie odpowiedzialne [13]. Wskaźniki ESG rodzą jednak wciąż spore kontrowersje. $Z$ jednej strony szeroko mówi się o tym, że zmiana klimatu sprawia, że kwestie ESG są siłą napędową inwestycji, z drugiej zaś pojawiają się głosy o ułomności ocen atrakcyjności inwestycyjnej opartej o tego typu wskaźniki. Najczęściej pojawiająca się obawa podnosi, że w przeciwieństwie do ratingów kredytowych, wyniki ESG są słabo skorelowane ze sobą oraz mało miarodajne, porównywalne i wiarygodne. Wciąż brak wystandaryzowanych jednoznacznych skal i metod pomiaru. Firmy zajmujące się oceną ESG nie zgadzają się jeszcze między sobą, co do tego, które z analizowanych firmy „są dobre, a które złe". W zależności od oceniającego rating może być skrajnie różny. Daje to duże pole do manipulowania ocenami i informacjami, na których rzeczywiście zależy inwestorom [14]. Jeśli dane ESG staną się bardziej dokładne i spójne, szefom i zarządzającym funduszami będzie trudniej angażować się w greenwashing [15], czyli tzw. zielone kłamstwo polegające na zatajaniu działalności destrukcyjnej na rzecz eksponowania wybranych inicjatyw proekologicznych.

$\mathrm{Z}$ ankiety przeprowadzonej przez Harvard Business Review na 413 specjalistach ds. globalnych inwestycji wynika, że $82 \%$ inwestorów uważa dane ESG za istotne dla wyników inwestycji. Dostarczają im informacji przede wszystkim na temat zagrożeń, w tym ryzyka wizerunkowego, prawnego i regulacyjnego. Jedna trzecia inwestorów spodziewa się, że w ciągu najbliższych pięciu lat ratingi ESG będą coraz częściej wykorzystywane do selekcji aktywów. Mimo, iż ratingi ESG zyskują na znaczeniu, w ankiecie wyczuwa się też sceptycyzm - 20\% inwestorów konsekwentnie twierdziło, że wskaźniki ESG nie wpływają na kurs akcji [16].

Mówiąc o presji wywieranej przez interesariuszy na biznes należy zauważyć, że trend ten szczególnie widoczny jest w Europie. To właśnie Europa wyznacza trendy i wprowadza regulacje dotyczące zrównoważonego inwestowania. Wyraźnym przykładem tego jest fakt, że w trakcie starań Ursuli von der Leyen o objęcie przewodnictwa w Komisji Europejskiej, które ostatecznie objęła w listopadzie 2019 roku, zobowiązała się do osiągnięcia celu redukcji emisji do 2030 r. o 50\%, zmierzając 


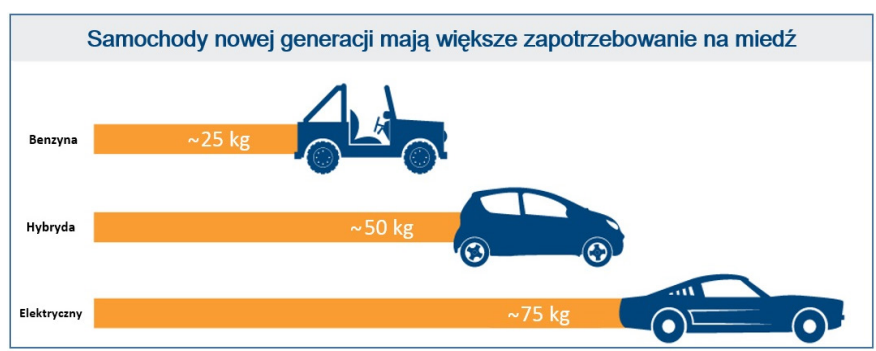

Rys. 2. Wykorzystanie miedzi w samochodach nowej generacji [Źródło: Opracowanie własne na podstawie Visual Capitalist, U.S. Global Investors] Fig. 2. Copper utilization in the new generation vehicles [Source: Own elaboration, based on Visual Capitalist, U.S. Global Investors]

do neutralności klimatycznej, polegającej na wyeliminowania gazów cieplarnianych w UE do 2050 r. Europejski Zielony Ład stanowić będzie ogromne wyzwanie nie tylko dla rządów krajów UE ale i dla biznesu, który zmuszony będzie przystosować się do nowych realiów [17]. Przedsmakiem wynikającym z lobbingu Unii Europejskiej na rzecz zrównoważonego biznesu są nowe obowiązki raportowe [18]. Obowiązek raportowania niefinansowego narzuciła w grudniu 2014 roku Dyrektywa Parlamentu Europejskiego i Rady 2014/95/UE. Część przedsiębiorstw rozpoczęła raportowanie niefinansowe zgodnie z Dyrektywą od 2018 roku, kolejne pierwszy raz przystąpiły do procesu w 2019 roku. Idea raportowania niefinansowego sprowadza się do wypracowania większej transparentności przedsiębiorstw oraz zachęcenia ich tym samym do poprawy raportowanych wskaźników. W dniu 18.06 .2019 opublikowane zostały nowe Wytyczne Komisji Europejskiej dotyczące raportowania niefinansowego, obowiązujące już przy raportach za 2019 rok. Wprawdzie formalnie nie są one wiążące, ale unijny organ nadzoru (ESMA) zaleca, aby krajowe organy nadzorcze dokonywały oceny raportów niefinansowych właśnie w oparciu o ten dokument. Rozbudowują one w bardzo istotny sposób wymogi raportowania i krąg podmiotów nim objętych. Nowe wytyczne przewidują szereg kolejnych złożonych pytań, kilka przykładów poniżej: [19]

- Proszę opisać wpływ ryzyka i możliwości związanych $\mathrm{z}$ klimatem na model biznesowy, strategię i plany finansowe przedsiębiorstwa;

- Proszę opisać sposoby zarówno pozytywnego, jak i negatywnego wpływu modelu biznesowego przedsiębiorstwa na klimat,

- Proszę opisać odporność modelu biznesowego i strategii biznesowej przedsiębiorstwa, $\mathrm{z}$ uwzględnieniem różnych scenariuszy związanych z klimatem w różnych perspektywach czasowych, w tym przynajmniej scenariusz zakładający ocieplenie na poziomie najwyżej $2^{\circ} \mathrm{C}$ oraz scenariusz zakładający ocieplenie o ponad $2^{\circ} \mathrm{C}$,

- Proszę opisać zależność przedsiębiorstwa od kapitału naturalnego, takiego jak woda, grunty, ekosystemy i różnorodność biologiczna, które są narażone na ryzyko ze względu na zmianę klimatu.

Unia Europejska swoimi regulacjami konsekwentnie zmierza do realizacji idei zrównoważonego rozwoju. Zachodzi jednak obawa, czy nie dzieje się to za wszelką cenę, kosztem rozwoju i dobrobytu poszczególnych państw i przedsiębiorstw, które być może nie będą w stanie przystosować się do narzuconych wymogów. Zastanawiające jest także to, jak regulacje będą wpływać w przyszłości na konkurencyjność europejskich firm na świecie, zmuszonych od stawania w konkury z firmami z krajów, które nie są obwarowane tak restrykcyjnymi przepisami, jak te narzucane przez UE.

\section{Branża wydobywcza na rzecz celów zrównoważonego rozwoju}

\subsection{Doświadczenia ze świata}

Gromadząc materiały do niniejszego artykuły sięgnięto do strategii i materiałów korporacyjnych 10 największych producentów miedzi na świecie. Każda $\mathrm{z}$ analizowanych spółek odnosi się w swoich strategiach w mniejszym lub większym stopniu do zrównoważonego rozwoju. Wiele z nich posługuje się celami zrównoważonego rozwoju wyznaczonymi przez ONZ. Wyraźnie widoczną praktyką jest odnoszenie się spółek do własnych działań na rzecz wspierania wybranych SDGs. Wiele spółek wybiera kilka konkretnych celów i buduje określone programy korespondujące z nimi. Jednym z najbardziej jaskrawych przykładów zaangażowania na rzecz zrównoważonego rozwoju jest największy producent miedzi na świecie - chilijskie, państwowe przedsiębiorstwo - Codelco.

W 2016 r. w Codelco opracowano plan na rzecz zrównoważonego rozwoju, który wedle zamysłu ma służyć spółce, jako mapa drogowa na następne 25 lat. Stanowi ona operacjonalizację strategii spółki w zakresie zrównoważonego rozwoju i odnosi się do krótko (do 2020 r.), średnio (do 2030 r.) i długoterminowej (do 2040 r.) perspektywy. Istotnym czynnikiem w każdym wymiarze czasowym jest dla Codelco minimalizowanie ryzyk i negatywnego wpływu społeczno-środowiskowego. Jako kluczowe elementy zrównoważonego rozwoju Codelco wskazuje: bezpieczeństwo i higienę pracy, pracowników, środowisko, społeczności lokalne, innowacje oraz ład korporacyjny. Spółka zwraca uwagę na swoje inwestycje na rzecz zrównoważonego rozwoju, operując konkretnymi kwotami i wskazując, że w 2017 r. na ten cel przeznaczyła 752 milionów dolarów. Jak deklaruje firma, środki te spożytkowano m.in. na inicjatywy związane z projektami BHP i ochronę środowiska, a także przedsięwzięcia związane $\mathrm{z}$ doskonaleniem systemu wychwytywania gazów oraz oczyszczania wód powierzchniowych i zarządzania odpadami. Codelco opisuje w szerokim zakresie także konkretne, zrealizowane działania i projekty na rzecz społeczeństwa.

Jednym na najciekawszych projektów, o którym warto wspomnieć w kontekście celów związanych z ochroną klimatu oraz czystą energią jest uruchomienie przez Codelco elektrowni słonecznej Pampa Elvira Solar. Elektrownia słoneczna, 
przyjazna środowisku obejmuje dziś obszar paneli słonecznych o powierzchni ok. $40000 \mathrm{~m} 2$. Elektrownia generuje rocznie ok. 54000 MWh energii, zastępując około 80\% zużycia paliw kopalnych, (oszczędzając do 6500 ton oleju napędowego rocznie). Spalając mniej oleju napędowego, kopalnia obniżyła emisję $\mathrm{CO}_{2}$ o prawie 15000 ton rocznie. Ponadto zmniejszenie zużycia oleju napędowego pozwala uniknąć rocznej mobilizacji 250 ciężarówek, które byłyby wymagane do transportu paliwa. To rozwiązanie z jednej strony dostarcza Codelco pewną energię po stabilnym koszcie, $z$ drugiej strony generuje zieloną energię, przyjazną środowisku. Doskonale pogodzono kwestie biznesowe ze środowiskowymi [20].

\subsection{Doświadczenia z Polski}

Polskie doświadczenia pokazują, że także spółki z naszego rodzimego rynku coraz lepiej rozumieją kierunek, w którym zmierza biznes. Branża wydobywcza jest jedną z tych, na które czekają najtrudniejsze wyzwania w kontekście przemian wynikających z szerzenia idei zrównoważonego rozwoju. Nie można wymagać, aby przedsiębiorstwa trudniące się wydobyciem surowców, tak istotnych z punktu widzenia wielu sektorów, nagle zaprzestały swojej działalności lub też prowadziły ją w sposób pozbawiający je zysku. Mogą natomiast wprowadzać zmiany do swoich procesów produkcyjnych, czyniąc je bardziej przyjaznymi środowisku, podejmować różnorodne inicjatywy prośrodowiskowe oraz na wiele sposobów uwzględniać dobro i potrzeby lokalnych społeczności. Jednymi z bardziej jaskrawych przykładów spółek angażujących się na rzecz zrównoważonego rozwoju, od kilku lat, są spółki z udziałem Skarbu Państwa. Duża w tym rola przyjętej w kraju polityki oraz realizowania założeń Strategii na Rzecz Odpowiedzialnego Rozwoju.

Przykładami spółek z branży wydobywczej a jednocześnie spółek z udziałem Skarbu Państwa są KGHM Polska Miedź S.A. oraz Jastrzębska Spółka Węglowa S.A. Przyglądając się aktualnym strategiom biznesowym obu spółek wyraźnie widać wpływ tego samego, głównego akcjonariusza ale także po prostu globalnych megatrendów. Podobieństwa obu strategii są bardzo wyraźne, co przedstawiono w Tabeli 1.

Jasno widać te same kierunki dotyczące zrównoważonego rozwoju, które przyświecają obu spółkom. Interesującą lekturą, na temat odpowiedzialnej postawy spółek oraz ich poszanowania dla założeń idei zrównoważonego rozwoju, są zintegrowane raporty roczne, szeroko omawiające kwestie pozafinansowej działalności spółek. Tam też można znaleźć przykłady konkretnych działań i inicjatyw podejmowanych przez spółki na rzecz środowiska, społeczeństwa, kultury i sportu [21]. Z uwagi na syntetyczny charakter artykułu nie jest on miejscem do opisywania ich wielości i różnorodności, ale warto się z nimi zapoznać, aby dostrzec starania branży, która stara się nadążać za przemianami i oczekiwaniami względem biznesu.

\section{Korzyści dla branży wydobywczej niesione za sprawą zrównoważonego rozwoju \\ 3.1. Popyt na miedź}

Zmiany szerzone przez ideę zrównoważonego rozwoju malują obraz trudnej przyszłości dla biznesu, który będzie musiał przystosować się do nowej rzeczywistości. Można nabrać przekonania, że prośrodowiskowa presja niesie ze sobą jedynie trudności i negatywne konsekwencje dla prowadzenia biznesu w obszarze górnictwa. Tymczasem zrównoważony rozwój, dbałość o klimat i zachodzące na świecie przemiany ukierunkowane na ochronę środowiska mogą generować wiele pozytywów dla niektórych branż. Jaskrawym przykładem jest tutaj górnictwo miedzi.

Prognozuje się, że elektromobilność, która stanowi jeden z obecnych megatrendów, znacząco napędzi światowe zapotrzebowanie na miedź. Według szacunków Europejskiego Instytutu Miedzi do 2027 r. zapotrzebowanie na miedź wzrośnie do 1,7 mln ton. W zależności od szacunków, mówi się o tym, że auta $\mathrm{z}$ napędem elektrycznym zawierają nawet cztery razy więcej miedzi niż auta $z$ silnikiem spalinowym. Przybliżone zawartości miedzi w samochodach różnego typu przedstawia Rysunek 2.

Miedź jest również intensywnie wykorzystywana w infrastrukturze niezbędnej do ładowania pojazdów elektrycznych. W całej Europie trwa proces rozbudowywania publicznych stacji ładowania. Do realizacji tego procesu również niezbędna będzie miedź. Surowiec ten, z uwagi na swoje właściwości, ma powszechne zastawanie $w$ takich obszarach, jak fotowoltaika, czy energetyka wiatrowa, poprawiając ich ogólną wydajność ekonomiczną. Miedź jest wykorzystywana m.in. do produkcji przewodów i kabli, paneli fotowoltaicznych oraz elementów wiatraków słonecznych (generatory, systemy uziemień, przyłącza kablowe). Oparte na miedzi i jej stopach technologie zwiększają efektywność energetyczną w kluczowych obszarach- energetyce oraz przemyśle [22]. Obserwacja czołowych megatrendów pozwala zatem sądzić, że widoczne na świecie przemiany, to nie tylko zagrożenia, ale również szanse związane z cywilizacyjnymi i technologicznymi przemianami. Przyglądając się światowym rynkom widać obszary, które w perspektywie dekad powinny generować popyt na miedź. Należy tu wskazać przede wszystkim na branże innowacyjne oraz stawiające właśnie na rozwiązania proekologiczne. Te dwie sfery naturalnie łączą się ze sobą. Tak jest nie tylko w przypadku elektromobilności ale także rozwoju odnawialnych źródeł energii, o czym już wspomniano w niniejszym artykule [23].

\subsection{Green copper i umowa $z$ BMW}

Kolejnym przykładem, ukazującym, że zrównoważony rozwój może stanowić pozytyw dla biznesu są próby przekuwania go na przewagę konkurencyjną. Skuteczne działania na tym polu podjęło chilijskie Codelco. W 2017 roku branżę surowcową zaskoczyła informacja, że Codelco planuje sprzedawać „nowy rodzaj” miedzi tzw. green copper [24]. Z kolei na rynek chiński miała być ona sprzedawana, jako feng shui copper. Jest to naturalnie ta sama miedź, jaką firma produkuje od lat, natomiast z certyfikatem poświadczającym jej odpowiedzialną i zrównoważoną produkcję, wskazując tym samym ukierunkowanie spółki na aspekty związane ze zrównoważonym rozwojem. Co ciekawe, rynek nie zareagował na tę informację, jak na fanaberię Codelco, przeciwnie, potraktowano ten pomysł bardzo poważnie. Financial Times opublikował artykuł, w którym opisał realne plany londyńskiej giełdy matali (London Metal Exchange - LME), aby zieloną miedź dodatkowo premiować [25].

Codelco podjęło też poważne negocjacje $\mathrm{z}$ branżą automotiv, aby zakontraktować dostawy na green copper. Jak 
wskazano w poprzednim punkcie artykułu, gwałtowanie rosnąca produkcja samochodów elektrycznych, powoduje rosnący popyt na miedź wśród producentów samochodów, zwłaszcza na rynku europejskim. W styczniu 2018 roku Codelco finalnie podpisało dużą umowę na dostawy miedzi dla BMW Group w ramach Responsible Copper Initiative. Grupa BMW i Codelco podpisały umowę o współpracy w zakresie zrównoważonych i przejrzystych dostaw miedzi. Od wydobycia metalu po instalację $\mathrm{w}$ samochodzie, Codelco i BMW Group tworzą punkt początkowy i końcowy w łańcuchu dostaw miedzi, tworząc tym samym warunki wstępne dla nowych standardów w zrównoważonym przetwarzaniu miedzi. Aby nakreślić skalę wielkości umowy wystarczy wskazać, że w 2017 roku BMW Group zakupiła od różnych dostawców 42 000 ton miedzi o wartości ponad 200 milionów euro. BMW Group, jako jeden z wiodących światowych producentów pojazdów elektrycznych, w 2025 roku będzie oferować aż 25 zelektryfikowanych modeli. Do tego czasu zapotrzebowanie na miedzi wzrośnie o 20000 dodatkowych ton [26]. Pokazuje to, że miedź będzie odgrywać jeszcze większą rolę w przyszłości przemysłu motoryzacyjnego, a spółka Codelco, jako jej producent zapewniła sobie stałego odbiorcę ceniącego zrównoważone wytwarzanie.

\section{Podsumowanie}

Świadomość konieczności uwzględniania założeń zrównoważonego rozwoju w biznesie wzrosła w ciągu ostatnich dwóch dziesięcioleci na całym świecie, również wśród firm wydobywczych. Obserwując zmianę postaw wśród przedsiębiorstw należy uznać, że coraz wyraźniej zdają sobie sprawę $\mathrm{z}$ tego, że prowadzenie dziś biznesu, to nie tylko koncentracja na zysku. Śledząc aktywność czołowych przedstawicieli branży wydobywczej można nabrać przekonania, że całkiem dobrze radzą sobie ze znajdowaniem złotego środka, łączącego aspekty zarobkowej działalności z godzeniem interesów społecznych i środowiskowych. Oczywistym jest, że ich działalność nie stanie się nagle zupełnie neutralna dla otoczenia ale staje się stopniowo coraz bardziej mu przyjazna i rekompensująca swój negatywny wpływ. Co więcej, sektor wydobywczy zaczął dostrzegać, że zrównoważony rozwój może przynieść mu korzyści i stawać się polem do kreowania przewagi konkurencyjnej. Przedstawione przykłady są tylko częścią szeroko zakrojonych działań podejmowanych przez sektor wydobywczy. W przyszłości temat ten będzie rozwijany w kontekście budowania skutecznych strategii biznesowych opartych o założenia zrównoważonego rozwoju, takich które dostarczą korzyści zarówno otoczeniu, jak i samym przedsiębiorstwom, kreując ich przewagę konkurencyjną. 


\section{Literatura - References}

1. „USA wychodzą z porozumienia paryskiego, Trump rozmija się z klimatem”, Polityka 5.11.2019

2. Mączyńska E. 2010: Naruszona równowaga, kryzys globalny a model ustroju gospodarczego, [w:] Skawińska, E. and Badzińska, E. Zarządzanie konkurencyjnością podmiotów, Poznań, Wydawnictwo Politechniki Poznańskiej, str. 9-25; Tutaj J., Rutkowska M. and Sulich A. 2019: Eco-innovation as an Element of Business Value and Performance Management, [w:] Jedlicka P., Maresova P., Soukal I., Hradec Economic Days, Hradec Kralove, str. 466-474.

3. Jonker J., Rudnicka A., Reichel J. 2011: Nowe horyzonty. Przewodnik po społecznej od-powiedzialności i rozwoju zrównoważonym, Centrum Strategii i Rozwoju Impact, Łódź

4. Płachciak A. 2011: Geneza idei rozwoju zrównoważonego, Ekonomia 5 (17) 2011, Wy-dawnictwo Uniwersytetu Ekonomicznego we Wrocławiu, Wrocław; Adamczyk J. 2017: Dy-fuzja koncepcji zrównoważonego rozwoju i społecznej odpowiedzialności przedsiębiorstw, Marketing i rynek 11/2017; Trzepacz P. 2012: Geneza i istota koncepcji rozwoju zrównowa-żonego, Zrównoważony rozwój- wyzwania globalne. Podręcznik dla uczestników studiów doktoranckich, Uniwersytet Jagielloński, Kraków 2012

5. Przekształcamy nasz świat: Agenda na rzecz zrównoważonego rozwoju do roku 2030, Rezolucja przyjęta przez Zgromadzenie Ogólne w dniu 25 września 2015 r.

6. Fiedor, B. 2002: Podstawy ekonomii środowiska i zasobów naturalnych, Warszawa, Wy-dawnictwo C.H. Beck

7. Jonek-Kowalska I. 2016: Koncepcja Zrównoważonego Rozwoju jako wyzwanie dla polskich przedsiębiorstw górniczych, Zeszyty Naukowe Politechniki Śląskiej 2016, Seria: Organizacja i Zarządzanie z. 95, nr kol. 1961

8. Dubiński J. 2013: Zrównoważony rozwój górnictwa i surowców mineralnych, Journal of Sustaineble Mining, Vol. 12 (2013), No 1

9. ICMM 2017 Industry Stakeholders Opinion Survey Final Report

10. Pearce Craig L., Maciariello Joseph A., Yamawaki H. 2013: Dziedzictwo Druckera, Oficyna Wolters Kluwer Polska, Warszawa, str. 15

11. „CEO bilionowego funduszu ostrzega biznes: musicie służyć społeczeństwu”, Busi-nessInsider.com 17.01.2018

12. Czerwonka M. 2013: Inwestowanie społecznie odpowiedzialne, Difin, Warszawa 2013, s. 21- 45.

13. „GPW uruchamia indeks WIG-ESG”, Komunikat Prasowy GPW z dnia 13.09.2019, Warszawa

14. „Climate change has made ESG a force in investing”, The Economist 07.12.2019

15. Witek L. 2013: Zjawisko greenwashingu a zachowania konsumentów, Zeszyty Naukowe Uniwersytetu Szczecińskiego, Problemy Zarządzania, Finansów i Marketingu nr 32, s. 124

16. „W jaki sposób inwestorzy korzystają z ratingów ESG”, Harvard Business Review Pol-ska, nr 181, marzec 2018

17. „Policymakers across the world turn their attention to sustainable finance”, Bloomberg Professional Services 13.12.2019

18. „Wytyczne KE w zakresie raportowania niefinansowego”, https://seg.org.pl/pl/wytyczne-ke-w-zakresie-raportowania-niefinansowego, dostęp 03.01.2020

19. Komunikat Komisji Europejskiej z dnia 20.06.2019 - Wytyczne dotyczące sprawoz-dawczości w zakresie informacji niefinansowych: Suplement dotyczący zgłaszania informa-cji związanych z klimatem (2019/C 209/01)

20. Raport Zrównoważonego Rozwoju Codelco za 2017 rok (Reporte de Sustentabilidad 2017); Sprawozdanie Codelco za 2018 rok (Memoria Anual 2018); Plan zrównoważonego rozwoju Codelco (Plan Maestro de Sustentabilidad)

21. Strategia KGHM Polska Miedź S.A. na lata 2019-2023; Strategia 2018-2030 z uwzględnieniem Spółek Zależnych GK JSW; Zrównoważony Raport KGHM Polska Miedź S.A. za 2018 rok, Raport Zintegrowany JSW za 2018 r.

22. „KGHM zaciera ręce. Elektromobilność napędzi zapotrzebowanie na miedź”, Busi-nessinsider 18.10.2018

23. „Kryzys etapem ewolucji. Geopolityka, ekologia, innowacje”, Puls Biznesu 02.01.2020

24. http://www.mining.com/codelco-produce-green-copper/, (data dostępu: 07.01.2020)

25. „Green revolution spreads to metals”, Financial Times, sierpień 2017

26. https://www.press.bmwgroup.com/global/article/detail/T0277850EN/bmw-group-and-codelco-agree-on-cooperation-to-establish-the-responsible-copper-initiative?language $=e n,($ data dostępu: 07.01.2020) 
The Mining Industry Facing Challenges Driven by the Sustainable Development Idea

The climatic crisis and its consequences are the issues provoking and an extensive discussion among various parties. A fierce pressure on authorities and, indirectly, on business representatives was posed by the UN in 2015 by adopting the "2030 Agenda" (Sustainable Development Goals). 193 countries have declared the willingness to join the initiatives aimed at sustainable development. How has the business answered to that call? Is any progress being made in the traditionally polluting industries, i.e. the mining sector? Does it mean that their time has come to an end? The above is one of many doubts rising upon getting familiar with the SDG. In the meantime, it turns out that the business, including the environment-harming industries, is learning how to benefit from the new order and make it their competitive advantage. The sustainable development initiatives are being reflected in the vast majority of mining companies' strategies. Directions set by the principles of sustainable development are aimed at bringing benefits for the business environment. However, we can already see that there is a clear tendency of companies attempting to make use of their responsible and sustainable approach. They consider it as an important part of their future success.

Keywords: sustainable development, mining industry, stakeholders, challenges 